\title{
$\mathrm{H}_{2} \mathrm{O}_{2}$ POTENTIATES TNF- $\alpha$ CELLULAR TOXICITY: REVERSAL WITH PROPOFOL
}

Authors: Tao Luo, $\mathrm{MD}^{1}$, Min Liu, $\mathrm{MD}^{1}$, Fang Wang, $\mathrm{MD}^{1}$, Qing-shan Zhou, MD, $\mathrm{PhD}^{1}$, Xian-yi Liu, $\mathrm{MD}^{1}$ and Zhengyuan Xia, MD, $\mathrm{PhD}^{1,2}$

Institutions: ${ }^{1}$ Anesthesiology research laboratories, Dept of Anesthesiology, Renmin hospital of Wuhan University; Wuhan, China; ${ }^{2}$ Faculty of Pharmaceuticals, The University of British Columbia, Vancouver, BC, Canada

\section{OBJ BCTIVE}

Tumor necrosis factor alpha (TNF) is a proinflammatory cytokine that can contribute to endothelium disorder in the pathogenesis of reperfusion injury. The present study was designed to test the hypothesis that oxygen free radicals can potentiate TNF cellular toxicity, which might be reserved by propofol $(\mathrm{P})$, an anesthetic with antioxidant properties, in human vascular endothelium cell line (ECV304).

\section{METHODS}

Cultured human ECV304 were either not treated (control), treated with $10 \mu \mathrm{mol} / \mathrm{L}$ hydrogen peroxide $(\mathrm{H} 2 \mathrm{O} 2, \mathrm{H})$, or treated with TNF-alpha $(40 \mathrm{ng} / \mathrm{mL})$ alone $(\mathrm{T})$ or TNF-alpha in the presence of $10 \mu \mathrm{mol} / \mathrm{L} \mathrm{H} 2 \mathrm{O} 2(\mathrm{H}+\mathrm{T}), 50 \mu \mathrm{M}$ propofol $(\mathrm{P}+\mathrm{T})$, propofol plus $\mathrm{H} 2 \mathrm{O} 2(\mathrm{P}+\mathrm{H}+\mathrm{T})$, respectively, for $24 \mathrm{hr}$. Cell viability was measured by MTT (3-[4,5-dimethylthiazol-2-yl]-2,5-diphenyltetrazolium bromide) assay, a widely used method in assessment of cytotoxicity and cell viability. The MTT assay result was compared to another cytotoxicity test, the LDH (lactate dehydrogenate) release assay. HUVECs apoptosis was assessed by flow cytometry, and compared to DNA ladder assay. Data were expressed as mean \pm SEM and analyzed with one-way ANOVA with multiple comparisons.

\section{RESULTS}

Following a $24 \mathrm{~h}$ exposure of the cells to TNF (40ng/ml), a significant reduction in cell survival, GSH-Px and SOD activities, as well as increases in lipid peroxidation product malondialdehyde (MDA) and LDH release were observed ( $\mathrm{P}<0.05$, $\mathrm{T}$ vs control). $\mathrm{H}_{2} \mathrm{O}_{2}$ at $10 \mu \mathrm{mol} / \mathrm{L}$ alone did not cause significant changes in GSH-Px and SOD activities ( $\mathrm{P}=\mathrm{NS}, \mathrm{H}$ vs control) and MDA production $(0.75 \pm 0.03 \mathrm{nmol} / \mathrm{mg}$ protein in $\mathrm{H}$ vs $0.69 \pm 0.04 \mathrm{nmol} / \mathrm{mg}$ protein in control, $\mathrm{P}>0.05)$, but it significantly enhanced TNF induced cell apoptosis, leading to still further deficiencies in antioxidant enzymes GSH-Px and SOD $(\mathrm{P}<0.05, \mathrm{H}+\mathrm{T}$ vs $\mathrm{T})$. In contrast, incubation of the cells with propofol prior to TNF exposure attenuated TNF-induced endothelial cell apoptosis $(\mathrm{P}<0.05$, $\mathrm{P}+\mathrm{T}$ vs T). Also, propofol abolished the effects of $\mathrm{H} 2 \mathrm{O} 2$ that sensitized endothelial cells to TNF toxicity.

\section{CONCLUSIONS}

Hydrogen peroxide, even at "trace" concentrations, may significantly enhance TNF induced endothelial cell apoptosis. Propofol has protective effects against TNF-induced cell toxicity by the reduction of oxidative injury, which might be beneficial for the treatment of reperfusion injury. 